\title{
A framework for multispecies assessment and management
}

Rindorf, Anna; Schmidt, Jörn ; Bogstad, Bjarte; Reeves, Stuart; Walther, Yvonne

Link to article, DOI:

10.6027/TN2013-550

Publication date:

2013

Document Version

Publisher's PDF, also known as Version of record

Link back to DTU Orbit

Citation (APA):

Rindorf, A., Schmidt, J., Bogstad, B., Reeves, S., \& Walther, Y. (2013). A framework for multispecies assessment and management. Nordic Council of Ministers. TemaNord No. 2013:550

https://doi.org/10.6027/TN2013-550

\section{General rights}

Copyright and moral rights for the publications made accessible in the public portal are retained by the authors and/or other copyright owners and it is a condition of accessing publications that users recognise and abide by the legal requirements associated with these rights.

- Users may download and print one copy of any publication from the public portal for the purpose of private study or research.

- You may not further distribute the material or use it for any profit-making activity or commercial gain

- You may freely distribute the URL identifying the publication in the public portal

If you believe that this document breaches copyright please contact us providing details, and we will remove access to the work immediately and investigate your claim 
Uili norden

A Framework for Multispecies Assessment and Management

An ICES/NCM Background Document

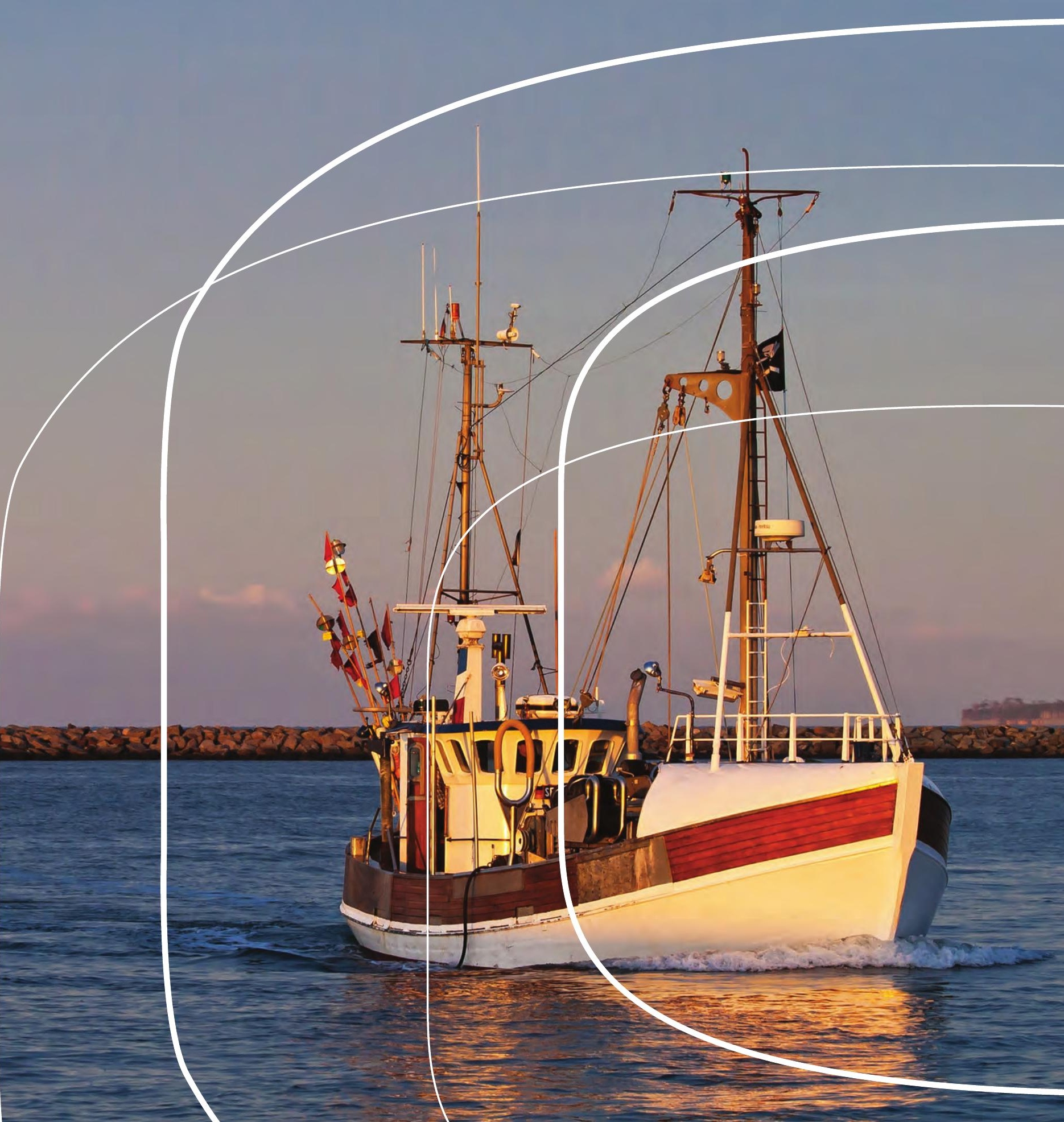



4 norden 



\section{A Framework for Multispecies Assessment and Management}

An ICES/NCM Background Document

Anna Rindorf, Jörn Schmidt, Bjarte Bogstad, Stuart Reeves and Yvonne Walther

TemaNord 2013:550 
A Framework for Multispecies Assessment and Management An ICES/NCM Background Document

Anna Rindorf, Jörn Schmidt, Bjarte Bogstad, Stuart Reeves and Yvonne Walther

ISBN 978-92-893-2584-4

http://dx.doi.org/10.6027/TN2013-550

TemaNord 2013:550

(C) Nordic Council of Ministers 2013

Layout: Hanne Lebech

Cover photo: ImageSelect

Print: Rosendahls-Schultz Grafisk

Copies: 316

Printed in Denmark

This publication has been published with financial support by the Nordic Council of Ministers. However, the contents of this publication do not necessarily reflect the views, policies or recommendations of the Nordic Council of Ministers.

www.norden.org/en/publications

Nordic co-operation

Nordic co-operation is one of the world's most extensive forms of regional collaboration, involving Denmark, Finland, Iceland, Norway, Sweden, and the Faroe Islands, Greenland, and Åland.

Nordic co-operation has firm traditions in politics, the economy, and culture. It plays an important role in European and international collaboration, and aims at creating a strong Nordic community in a strong Europe.

Nordic co-operation seeks to safeguard Nordic and regional interests and principles in the global community. Common Nordic values help the region solidify its position as one of the world's most innovative and competitive.

Nordic Council of Ministers

Ved Stranden 18

DK-1061 Copenhagen K

Phone (+45) 33960200

www.norden.org 


\section{Content}

Preparation of this document........................................................................................... 7

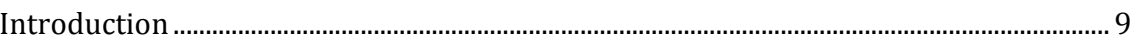

Determining the line between the science and the policy domain............................10

Identifying objectives .......................................................................................................11

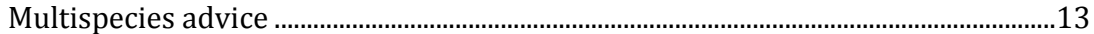

Communication and form of advice..............................................................................3

Applying the framework in other ecosystems .............................................................35

Acknowledgements ......................................................................................................

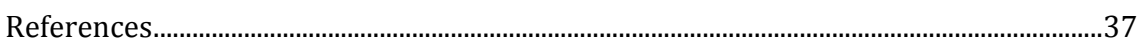

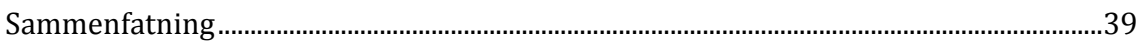

Annex 1 Workshop Summary .........................................................................................

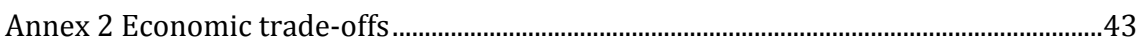





\section{Preparation of this document}

This document was build upon the work developed in expert groups of the International Council for the Exploration of the Sea (ICES) and international and national projects with input from the ICES/NCM Workshop on Technical Guidelines for Multispecies Management. The core group of experts consisted of Anna Rindorf, Jörn Schmidt, Bjarte Bogstad, Stuart Reeves and Yvonne Walther. Additional presentations at the workshop were given by Eskild Kirkegaard (DTU-Aqua) and Yimin Ye (FAO). The document was reviewed by Jeremy Collie (URI). The work was supported by the Nordic Council of Ministers (NCM) and ICES. 



\section{Introduction}

1982 United Nations Convention for the Law of the Sea in Article 119, 1(a) states that Member states should:

“...take measures which are designed, on the best scientific evidence available to the States concerned, to maintain or restore population of harvested species at levels which can produce the maximum sustainable yield, as qualified by relevant environmental and economic factors, including the special requirements of developing States, and taking into account fishing patterns, the interdependence of stocks and any generally recommended international minimum standards, whether subregional, regional or global."

The FAO (2003) guidelines for an Ecosystem Based Approach to Fisheries Management follows a pledge from the World Summit on Sustainable Development to account for the complex interplay between ecosystems and fisheries. The guidelines state that the understanding and management of fisheries should explicitly take into account interactions between stocks as well as social and economic considerations. Though it is acknowledged that only human activities can be managed, their optimal management will depend on the ecosystem in which they take place. Hence, the direct and indirect impact of fisheries on the marine ecosystem and vice versa must be assessed and predicted to provide management advice in support of the Ecosystem Based Approach to Fisheries Management. This entails a move from single species to multispecies advice as the management of one component of the ecosystem will depend on that of other components.

Species and fisheries interact in numerous ways in the ecosystem. One of the most basic interactive processes is that of predators feeding on their prey. In contrast to issues such as mixed catches in fisheries which can potentially be lessened through changes in fishing practices, the interaction between predators and prey can only be affected through changing the numbers of prey and/or predator. These interactions results in trade-offs between yield or abundance of different species, and robust scientific advice must therefore be accompanied by increased communication between science and policy. This communication must include a clear definition of the responsibilities of scientists, stakeholders and policy makers to avoid policy prescribing science or science prescribing policy. 
This document proposes a framework for producing multispecies management advice in an attempt to advance the international debate, and to show the benefits of applying multispecies management in the wider ICES area. In this framework, we emphasize the importance of the interface between science and policy; this includes a) the delineation of the scientific domain, b) the scoping process to develop objectives, i.e. give boundaries of the decision space and c) the communication of the advice. Additionally, an example for estimating economic trade-offs is given in annex 2.

In the European context, addressing the effect of predator-prey interactions is at the core of multispecies management advice (ICES 2012a) whereas aspects of mixed catches of several species are usually referred to as mixed fisheries advice (ICES 2012d). The suggested framework applies to both types of advice, but for simplicity the example focuses on multispecies advice in Northeast Atlantic waters. To demonstrate the direction of future work on multispecies advice, an example including technical interactions is also addressed. The framework is developed for data rich systems, but as a framework, it is generic and can be applied in both data rich and data limited contexts.

\section{Determining the line between the science and the policy domain}

Drawing the line between science and policy domains is a key issue when providing advice for management. This distinction should be defined by scientists, stakeholders and policy makers in common, thereby ensuring that scientific integrity is maintained and policy decisions are made by policy makers rather than scientists. The definitions of domains can be derived from workshops with a broad representation of industry representatives, NGOs, policy makers and scientists.

As an example of this, the location of the border between science and policy was discussed at two different stakeholder scoping sessions, a workshop where the majority of the participants were stakeholders from industry representatives, NGOs and Commission level managers (ICES 2012b) and a separate session where the majority of the participants were national managers (ICES/NCM workshop 2013, this report). At both sessions it was concluded that trade-offs between species should be made by policy makers based on advice from scientists. None of the group participants felt that policy makers should be obliged to follow the presented scientific trade-off options such as the maximum total tonnes 
landed (trading one $\mathrm{kg}$ of a species landed to one $\mathrm{kg}$ of another species), maximum value landed (trading one monetary unit of a species landed value to one monetary unit of another species) or maximum rent in fisheries (trading one monetary unit of profit for a species landed value to one monetary unit of profit of another species) by the letter. The tradeoffs will be particularly complicated when different nations are involved and one is predicted to gain while other are likely to lose. However, the expressed opinion was that this type of analysis could provide valuable information for discussing trade-offs. Hence, it is the task of scientists to provide the options from which policy makers choose, making the tradeoffs clear in every case. To avoid excessive numbers of options, these should be in accordance with the stated objectives as well as consistent with the precautionary principle.

\section{Identifying objectives}

There are many ways to identify objectives, including reviewing existing guidance in legislation and formal scoping sessions. The former has the advantage of often being considered by a wide range of stakeholders as absolute and hence giving appropriate objectives for a more detailed investigation. In contrast, the latter is likely to result in more debate and less temporal stability as objectives reflect the latest knowledge and political environment.

In the example chosen here, we found the reflection of the latest knowledge to be of greater importance than stability and hence used scoping sessions to identify objectives. The stakeholder scoping sessions were as in the previous section, a workshop where the majority of the participants were stakeholders from industry representatives, NGOs and Commission level managers (ICES 2012b) and a separate session where the majority of the participants were national managers (ICES/NCM workshop 2013, this report).

There was agreement in the workshops that scientists should delimit the space for sustainable exploitation within acceptable limits of impact on the environment, and inform policy makers and managers of the sustainable limits and consequences of trade-offs. The outputs of multispecies analyses should focus on "what if?" questions such as "what will happen if predatory fish are fished at $\mathrm{F}_{\mathrm{MSY}}$ ?" Whereas the opinion in the first workshop was that a large range of options could be presented to policy-makers, the opinion in the second workshop was that large numbers of options decreased clarity and a lower number was preferable. 
Potential scenarios identified in the first workshop included maximising the proportion of single species MSY on average across species, eliminating unprecautionary scenarios, including some "extreme" scenarios, which maximise each species, and considering the impact of the recovery of predatory fish. The first workshop also concluded that different stakeholders are likely to have different perceptions of risk, and also be likely to have different acceptance thresholds of risk of missing the stated objectives. At the second workshop concerns were raised about the cost that might be related to the need for ecosystem and multispecies assessment and advice. It was also raised that $\mathrm{F}_{\text {MSY }}$ reference points could be less precautionary when derived from a multispecies assessment than in single species assessments.

In some areas and within our current modelling environments, a minority of species interact in a manner that can provide policy choices (i.e. despite a large number of species included in some models, few species interacted in a manner that provided different outcomes for certain policy choices). Thus even in a complex system the policy choices might be fewer than currently perceived (see page 25 and onwards). The first workshop considered that including spatial or fleet issues in considerations could potentially blur the line between science and social advice. This concern was expressed at the second workshop regarding policy choices suggesting trade-offs between countries.

The first workshop noted that the multispecies advice will probably be communicated and discussed by EU parliamentarians. Thus care should be taken when writing the advice to ensure that it is clear and understandable to a broader range of stakeholders. Communication was also brought up as a crucial issue in the second workshop as complex information needs to be simplified and integrated into the advisory process. The need for making informed trade-offs increases the necessity of providing intelligible results for policy makers even further.

At both workshops, there was agreement that multispecies assessment and advice is clearly needed and that a major challenge of the process is the communication between science, stakeholders and decision makers. Both workshops concluded that multispecies advice should be:

- Precautionary.

- Providing yields close to MSY.

- In accordance with ecosystem constraints.

- Possible to communicate to managers and policymakers. 


\section{Multispecies advice}

Once the scientific domain is clearly delineated and the most important objectives for management defined, the scene is set for multispecies advice. To enhance clarity a general format for advice for all areas is defined here, describing the essential aspects of multispecies advice.

At the heart of all multispecies advice lies knowledge about interactions between species. Hence, multispecies advice should always contain a description of the ecosystem including species interactions. Without a general understanding of the ecosystem, the effects of different management scenarios cannot be reliably evaluated. From this general description of the ecosystem, the most important interactions which affect management of fisheries should be identified. These are the aspects for which trade-offs may occur which need to be taken into account in strategic management. Advice on the important trade-offs should follow to give the necessary basis for strategic advice as well as for tactical advice. Examples of multispecies advice will be laid out in the following sections. The actual advice could easily follow this format without necessarily having the same depth of information in each ecosystem.

In summary, the suggested format for multispecies advice is:

- A description of the ecosystem including species interactions.

- An identification of the most important interactions which affect management of fisheries.

- Advice on the important trade-offs which should be considered in fisheries management.

The examples given are all from data rich systems. However, the framework can also be used in data limited areas where even vague ideas about the effects of species interactions may be useful in ensuring precautionary and optimal management. Further, the framework can be applied to mixed fisheries issues by adjusting the first section, the description of the ecosystem, with a section describing the species composition of different fisheries.

\section{A description of the ecosystem including species interactions}

All species within a given ecosystem interact either directly or indirectly. The description of these interactions is a prerequisite to understand the system and the interconnections, which will possibly influence the management of one or more species within this system. The main interaction affecting yield in systems where several trophic levels are exploited is 
predation. Many commercial fish species eat other fish, and thus may consume large quantities of other commercial species. For young fish and small species, mortality due to predation is often substantially higher than fishing mortality. Several species, including cod, are also cannibalistic. The effect of predation on the various prey species has been studied for decades and hence information on interactions of these species exists for a wide range of marine ecosystems. Competition between species also occurs and is influenced by the availability of prey, which often is not managable but still influences the managed species. All interactions depend on the temporal and spatial overlap of species. In addition to species interactions, other drivers within a given system, such as fishery or environmental drivers, may change over time. Thus a description of the ecosystem should list:

- The main actors and their interactions,

- The main environmental drivers and human pressures affecting the ecosystem, and

- How the interactions have changed over time.

\section{Selecting examples}

The effects of species interactions can be grouped into three categories: Mortality due to predation, food limited growth and food competition between species. Frequently, only some of the interacting species are harvested, and the strength of climate effects on the individual species and the interactions differs considerably between systems. We here present the main interactions in three areas: Baltic Sea, North Sea and Barents Sea, which together illustrate the diversity both in the form of the interactions and in how many of the interacting species are harvested. In these systems, stomach sampling and gastric evacuation rate models have been used to quantify the diet composition by predator species and size/age and multispecies models have been set up to study these interactions. These models are the basis for the results presented in the examples below.

The examples are chosen to illustrate three types of systems:

- An ecosystem where the majority of the fish biomass consisting of just a few species, which are all commercially exploited while mortality from other sources is low.

- An ecosystem where charismatic top predators exert a large influence on a variety of exploited species. 
- An ecosystem where the abundance of food for commercially exploited species varies greatly due to environmental fluctuations.

As examples of these three system types, we have chosen a) the Baltic Sea, b) the North Sea and c) the Barents Sea. For these three systems, we will provide examples of issues which can be addressed under each of the three aspects: the description of the ecosystem, a definition of the most important interactions which affect management of fisheries and advice on the important trade-offs which should be considered in fisheries management, and describe why the consideration of these issues is important to management.

\section{The Baltic Sea - sketch of interactions}

The Baltic Sea is the largest brackish-water region in the world with most of its inhabiting species living at the margins of their distribution. It is characterized by strong horizontal salinity gradients, from the nearly marine southwestern part towards the almost fresh water northeastern part. The Baltic Sea also exhibits broad, flat coastal regions and an array of deeper basins, in which the different water bodies of fresh water at the surface and saline water in the deeper parts exhibit strong vertical gradients, preventing vertical mixing of the water bodies. In addition, biogeochemical processes in the deep basins consume the dissolved oxygen, which lead to oxygen deficiency. Only the inflow of oxygen-rich North Sea water can renew the water bodies and increase the oxygen content. These inflows have been scarce in recent decades and it is difficult to predict their frequency in a changing climate. Thus the system is strongly influenced by changes in environmental conditions.

The majority of the Baltic Sea fish biomass consists of just a few species, which are all commercially exploited: cod, sprat and herring (Figure 4.1). The fisheries on these commercial species are managed according to scientific advice and thus all components of the system are responsive to management. This is an example case of where all main species interacting are commercially exploited with important effects of climate, growth competition and strong predation interaction. All these interactions will vary with changes in climatic conditions, which may considerably affect the spatial distribution and thus the overlap between species. Competition between species is generally considered to be less important than predation and food limited growth, although there are signs of changes in weight-at age in herring due to competition for food with the large sprat stock (Casini et al. 2006). 
In the last decades, the Baltic ecosystem has experienced several important changes causing regime shifts and trophic cascades (Casini et al. 2009, Möllmann et al. 2009). The 1980s regime shift in the Baltic caused the fish community to shift from cod dominated system to a clupeid (herring and sprat) dominated system (Rudstam et al.1994). Cod recruitment declined due to unfavourable salinity and climate condition and recruitment suffered from cannibalism and predation on eggs and early life stages from herring and sprat (Köster 2000). The declining cod stock coinciding with a decrease in temperature favoured clupeids (Casini et al. 2008). In the changed ecosystem, competition for food between sprat and herring affected their growth and condition (Casini et al. 2004). Herring showed a decrease in mean weight at age with a spatial gradient towards north where sprat was more abundant.

Figure 4.1. Interactions between the three major commercial species in the Baltic Sea

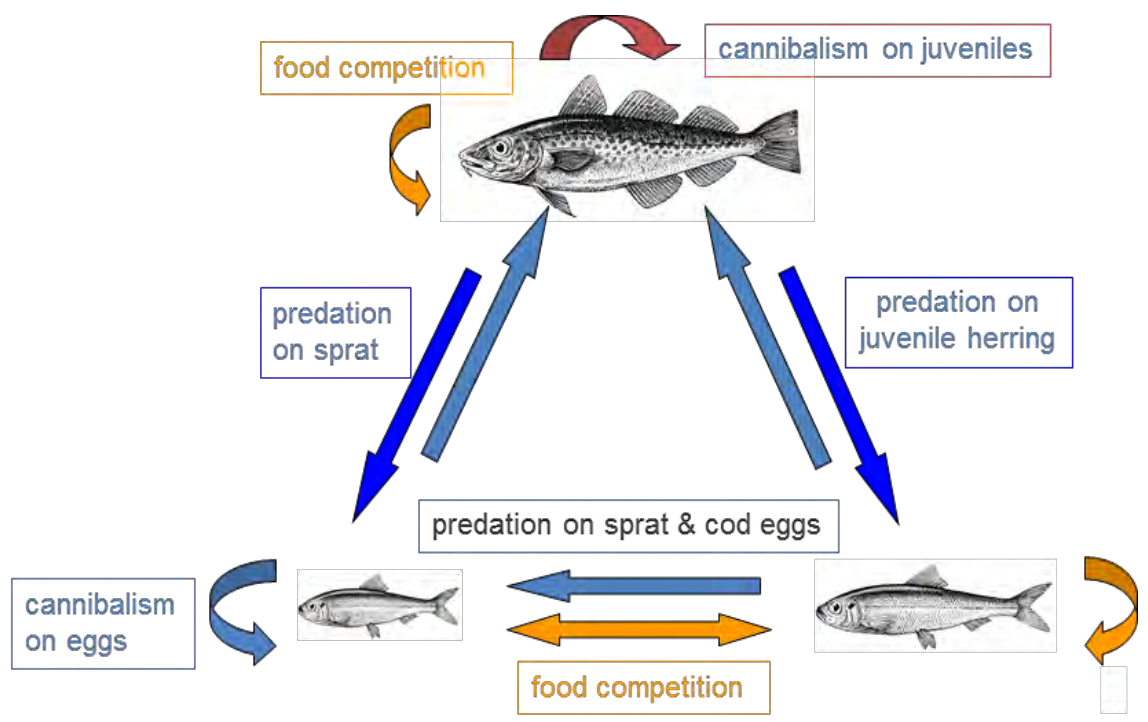

Note: Cod (top), herring (bottom right) and sprat (bottom left). Predation depicted in blue, food competition in orange and cannibalism in red.

\section{The North Sea - sketch of interactions}

The North Sea is a temperate sea strongly influenced by the exchange with Atlantic water masses. Warm, salty water is transported in, leading to comparatively warm temperatures in the winter and absence of a significant ice cover. The low average depth of 50 meters allows almost complete mixing of the water column leading to a welloxygenated water body. Thus the main climatic driver in the North Sea 
is the change in water temperature. The warming in the past has already led to changes in species distribution with a general northward shift (Perry et al. 2005). Coastal areas are influenced by frontal systems, tides and river plumes, which might partly change due to changes in currents making predictions difficult.

In the North Sea, charismatic top predators form an important part of the ecosystem. There are numerous fish-eating seabird species, at least five species of marine mammals and a variety of fish-eating fish, some of which spend only part of their time in the area. The fish species can be divided into four categories: forage fish, fish which eat small fish, benthic feeding fish and fish which eat large fish (top predators). Forage fish feed on plankton in the water column and the majority of the species such as sandeel, sprat and herring are targeted directly by the fishery. Fish that eat small fish belong to a range of species including some that are targeted by fisheries (e.g. haddock and whiting), some which are only occasionally landed (such as grey gurnard and starry ray) and some which mainly occupy the North Sea in specific seasons (such as mackerel and horse mackerel). Benthic feeding fish include, e.g. flatfish, which feed on prey in or near the bottom and the majority of these fish eat only minor amounts of commercial fish species. The main predators of larger fish are large cod and saithe, which have a diet consisting mainly of fish of a wide range of species. In a complex system like this, there are numerous interactions to consider (Figure 4.2). Firstly, top predator fish exert mortality on all other fish, and maintaining high stocks of these species affects the yield of other species that can be sustainably harvested. Secondly, species like seabirds and marine mammals are not commercially exploited and hence affect the targeted commercial fish without being responsive to any management measure apart from by-catch limitation measures and effects caused by the exploitation of their prey. Thirdly, the North Sea has targeted fisheries for all the important forage fish species in the system, hence presenting possible trade-offs between forage fish fisheries and predator performance. 


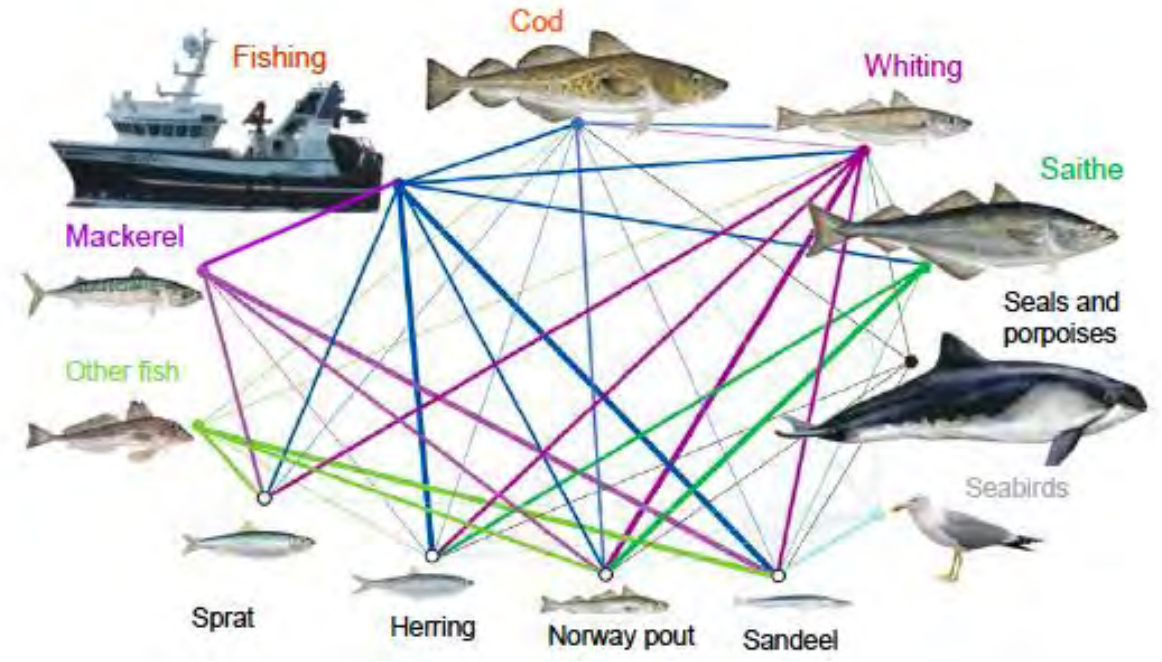

Note: Other fish include grey gurnard, Horse mackerel and starry ray. Seabirds include fulmar, gannet, great black backed gull, guillemot, herring gull, kittiwake, puffin and razorbill and seals and porpoises include grey seal and harbour porpoise. Colour of the lines indicates which predator the species is eaten by, the thickness of the lines indicates the biomass removed in this interaction (average from 1963-2010) (ICES 2012a).

\section{The Barents Sea - sketch of interactions}

The Barents Sea covers the continental shelf north of the Scandinavian Peninsula. The inflow of warm Atlantic water as well as the oceanatmosphere fluxes influence the regional ocean climate. One of the major changes influencing the biology is the ice cover. The area covered by ice reached an all-time low in recent years; thus the habitat suitable for cod has increased considerably, and cod have been observed as far north as $82^{\circ} 30^{\prime} \mathrm{N}$. In the Barents Sea, cod is the most important species for commercial fisheries as well as the dominant piscivorous species. Other important piscivorous predators in the system are harp seals and minke whales (Figure 4.3), which drive the natural mortality of the main commercial species cod, capelin and herring. Food abundance of Barents Sea cod varies greatly due to prey recruitment fluctuations and this influences both the growth and sexual maturation. The major prey species are capelin and herring, with capelin exhibiting marked variation over time. At the base of the food web are krill and amphipods, which are important prey for all of the mentioned fish species. Changes in their biomass are mainly related to environmental fluctuations. This system is an example case of a system with strong predation interactions, occa- 
sionally strong food limitation, and some species which are exploited at a very low rate but prey on managed species (marine mammals).

\section{Figure 4.3. Barents Sea multispecies interactions}

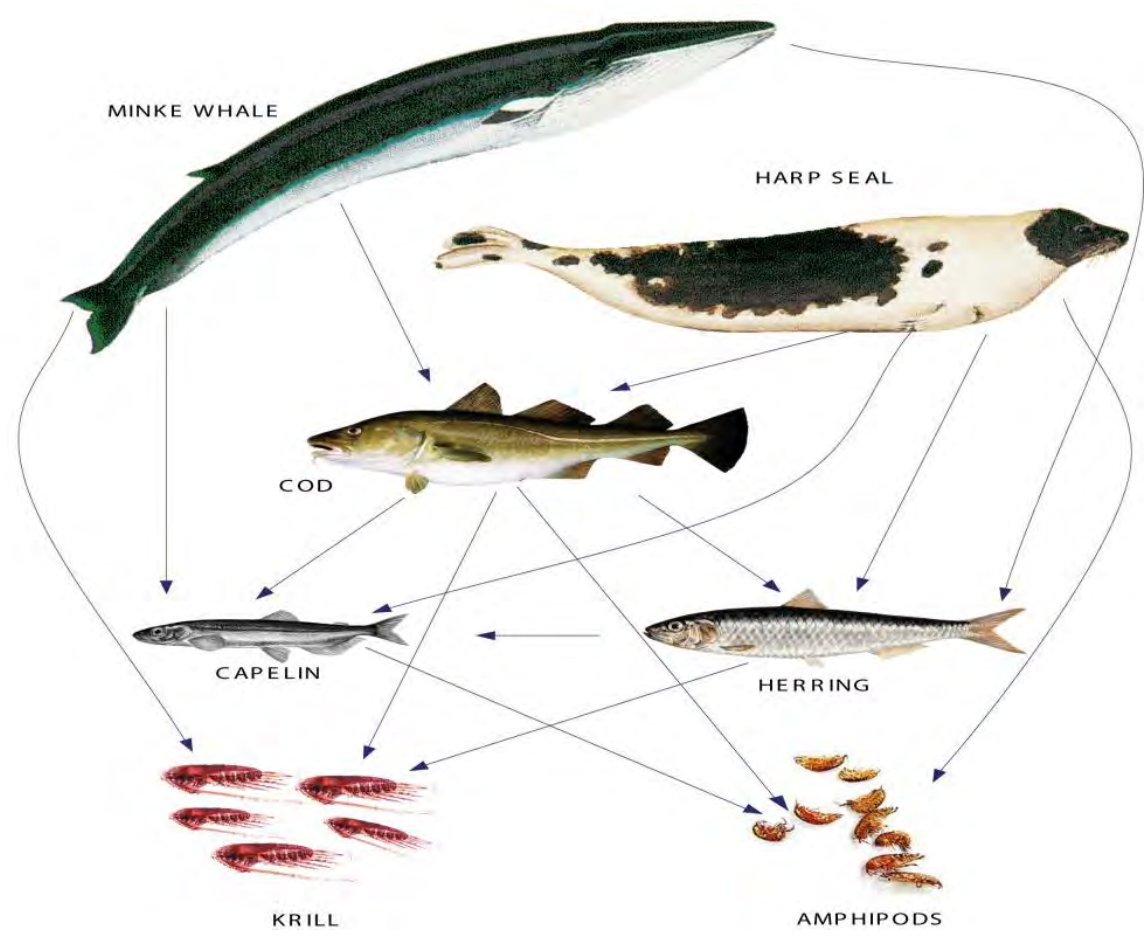

Note: Cod prey on capelin, herring and young cod (cannibalism), and herring prey on capelin larvae. Cod growth and maturation may be severely affected by lack of prey.

\section{Identification of the most important interactions which affect management of fisheries}

Information on community and food web indicators is crucial for the evaluation of interactions and responses in a multispecies context. Indicators are used to aid management by identifying the key signals within the environment and ecosystem expected to reflect processes that significantly influence the advice. Intensive work on developing community and food-web indicators has been performed under (i) ICES/JRC guidelines for establishing ecosystem indicators used to assess Good Envi- 
ronmental Status under the Marine Strategy Framework Directive, ${ }^{1}$ ii) Ecosystem indicators defined under the EU Data Collection Framework ${ }^{2}$ (DCF), and (iii) OSPAR Ecological quality objective indicators. ${ }^{3}$

The indicators currently used in creating multispecies advice are based on predation but can in future include other interactions. General community indicators could be:

- Natural and total mortality by age.

- Percentage of total mortality caused by natural sources.

- Proportion of large fish in community.

- Biomass by guild (for example forage fish).

- Spatial distribution pattern and area occupied.

- Condition factor or mean weight at age.

Indicators of a more general character will be applicable for most ecosystems, like e.g. species interactions as described above in the North Sea and Baltic Sea. Yet some ecoregions will have additional indicators that are important factors to consider such as described in the Baltic Sea example where salinity and climate triggered a regime shift (Möllmann et al. 2011).

Of these indicators, some are likely to be of greater importance to management than others, either because they are directly influenced by exploitation or because they have a significant impact on e.g. yield of fisheries. These indicators should be identified and their development followed in detail. The following sections describe examples of key interactions identified for the three regions.

${ }_{1} \operatorname{COM}(2010) 477$.

2 http://datacollection.jrc.ec.europa.eu/dcf-marine/variables

${ }^{3} \mathrm{http}: / /$ www.ospar.org/content/content.asp?menu=00690302200000_000000_000000 


\section{Example Baltic: Food dependent growth of cod}

After inaugurating a multiannual plan in 2007 the cod stock started to show signs of recovery (The European Commission, 2007). Yet unexpected side effects developed; the spatial distribution of the cod stock had changed to be concentrated to the southern part of the Baltic (Figure 4.4) whereas the herring and sprat stock is now more concentrated in the north. The spatial differentiation in the stock has resulted in a declining individual growth rate for cod. In recent years, the proportion of cod that are in a very poor condition has increased to $15 \%$ whereas it was very low previously (Eero et al. 2012; Figure 4.5). This poor condition is confirmed by fishermen who report on emaciated cod that are not marketable. As cod is cannibalistic, less alternative prey species will also lead to an increase in the consumption of juvenile cod. In addition, the commercial fisheries compete with cod for the larger herring in the southern areas of the Baltic. Herring landings are slowly increasing from the southern area, where cod food deficiency is a problem, and as the herring stock is adviced on in a single species format, the increase could lead to increased landings from areas where the cod seems to be food limited. An abrupt change in the balance of an ecosystem as the one experienced in the Baltic had severe implications for assessment and management of the stocks and eventually the reference points were revisited and reconsidered (ICES 2008). Multispecies management and an ecosystem-based approach to management would probably have provided a clearer picture of the problem.

Accounting for multispecies and spatial considerations in management could prevent further cascading effects. Looking from a single species assessment, the cod, herring and sprat stocks are currently all increasing (ICES 2013). Consequently it is not just about managing the single species components in isolation as underlying factors such as spatial predator prey overlapping may cause severe effects in a longer perspective. 


\section{Figure 4.4}
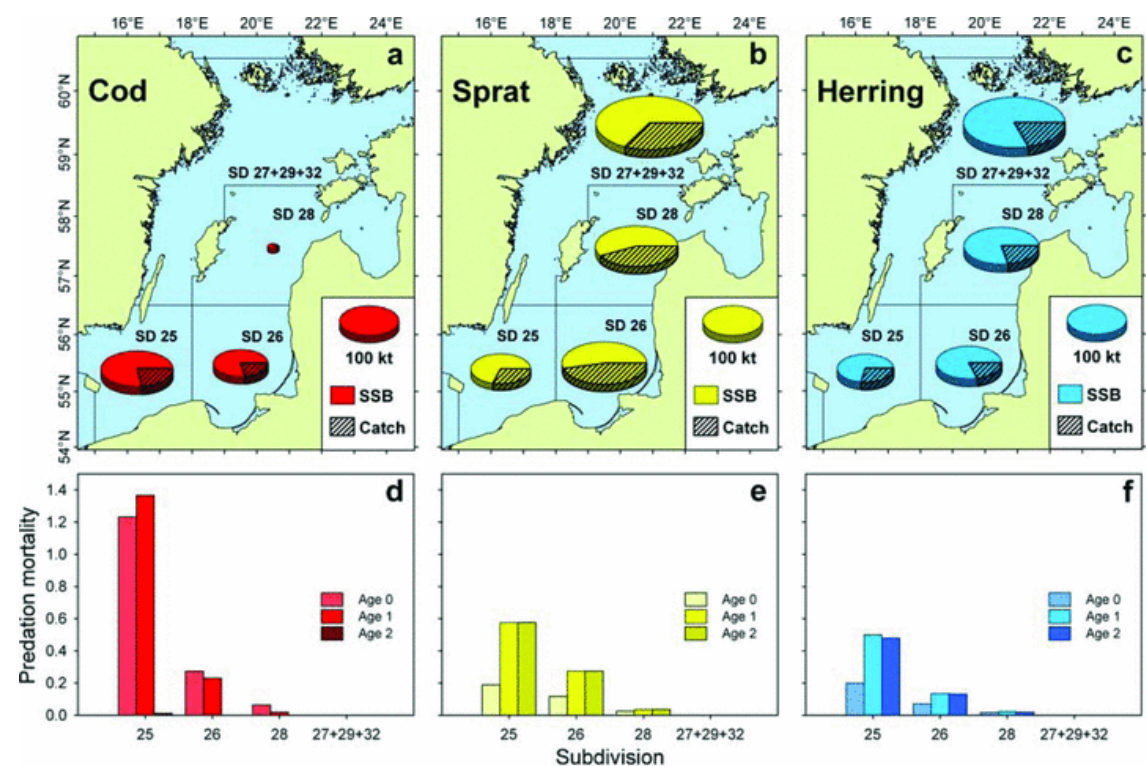

Note: Panels $(\mathrm{a}-\mathrm{c})$ : Spawning stock biomass (SSB) of cod, sprat and herring, including the proportion of catch (shown as sectors of SSB), by area (Subdivisions [SD]), in 2010. Panels (d-f): Predation mortality of cod, sprat, and herring, for age-groups $0-2$, by area (based on average estimates for 2009-2010). Reproduced from (Eero et al. 2012).

\section{Figure 4.5}

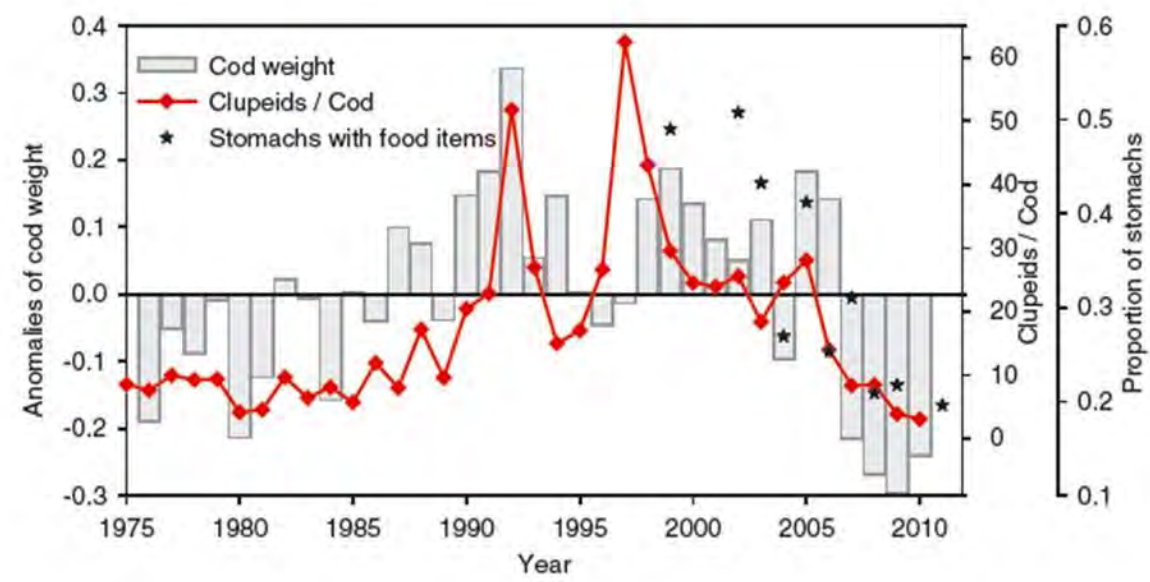

Note: Anomalies in mean weight of cod (average of age-groups 4-7) in SD 25 (bars) compared with changes in the biomass of clupeids (sprat and herring) relative to the number of adult cod (at age 4 and older) in the same area (line). The stars show the proportion of cod stomachs containing food items (Eero et al. 2012). 


\section{Example North Sea: Effect of seals on North Sea cod}

Over the past decade, a large management effort has been exerted to decrease catches of cod in order to allow the North Sea cod stock to recover to levels above precautionary reference points and to ensure management in accordance with the MSY principle. This effort resulted in a decrease in reported catch corresponding to a decrease in fishing mortality of around $50 \%$ compared to that in the year 2000. This should have resulted in a swift recovery of the cod stock to levels compatible with MSY management as the stock responded to the decrease in total mortality. However, the age composition of cod did not recover as anticipated and it was necessary to adapt the stock assessment to account for a large mortality from an unknown source affecting large cod (up to $49 \%$ in the years 2007-2010), and the resulting decrease in fishing mortality of only $30 \%$. This unknown source of mortality was significant in all years from 2001 onwards. It was hypothesised that it was a result of increased discards or unreported landings and efforts to control these would be necessary to rebuild the cod stock.

During the same time period, the grey seal population in the North Sea increased to levels beyond what had been seen during the past 40 years. Grey seals feed predominantly on fish and are able to take large prey like two- or three-year old cod. When the consumption by marine mammals was included in the model of cod natural mortality, the unallocated mortality was no longer significant in the period from 2008-2010. Hence, the conclusion reached by some that the lack of speedy recovery of the cod stock could be blamed on discards and unreported landings could at least be questioned.

The initial lack of knowledge of the possible causes of the unallocated landings did not cause substantial differences in the implemented management of the North Sea cod stock. However, the lack of understanding about the processes behind this mortality, and the effect fisheries management might have on these, led to a situation where advice was overly optimistic about the time required to recover the cod stock as the proportion of the fish dying from natural sources was underestimated when performing the forecasts. This could lead in time to lack of trust in both management and scientists. 

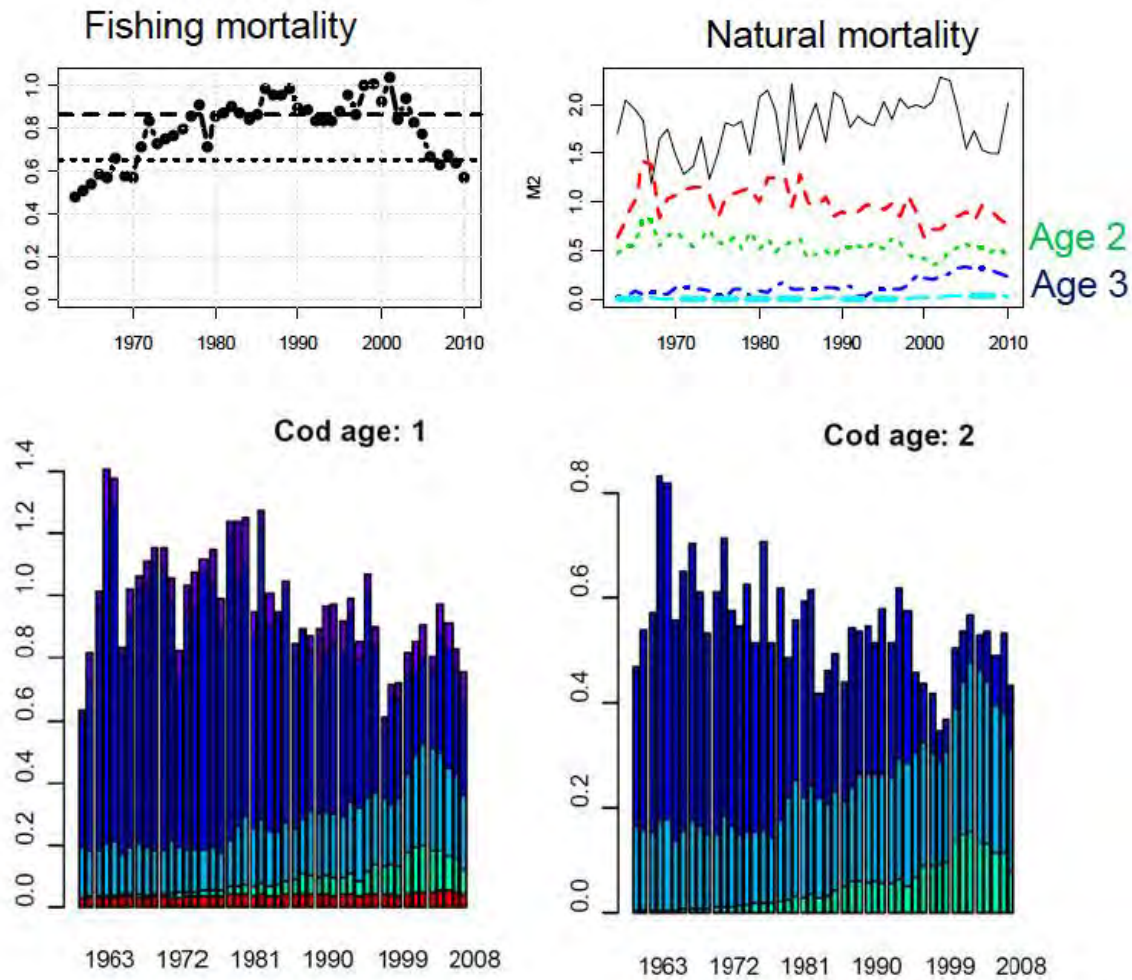

Note: Fishing mortality and natural mortality of cod (top) and sources of natural mortality of 1 and 2-year old cod (bottom, red: seabirds, dark blue: cod, medium blue: harbour porpoise, turquoise: grey seal). ICES 2011.

\section{Example Barents sea: capelin effect on cod growth}

Individual growth of cod in the Barents Sea has varied strongly over time, and suddenly dropped to a very low level in 1987-1988. The growth decline was then related to a collapse in the capelin stock, which is the main prey for cod. Subsequently, there have been two more capelin collapses with much smaller effects on cod growth, which is probably due to much higher abundance of other fish prey during these later collapses (Figure 4.7). The growth decline caused considerable problems for the cod assessment and predictions, as cod weight at age was much lower than predicted. Thus the realized fishing mortality corresponding to a given TAC became much higher than the recommended fishing mortality as more individuals had to be caught in order to obtain a given catch in biomass. The opposite happened a few years later when the cod growth increased to a very high level following the recovery of the capelin stock. 
Figure 4.7

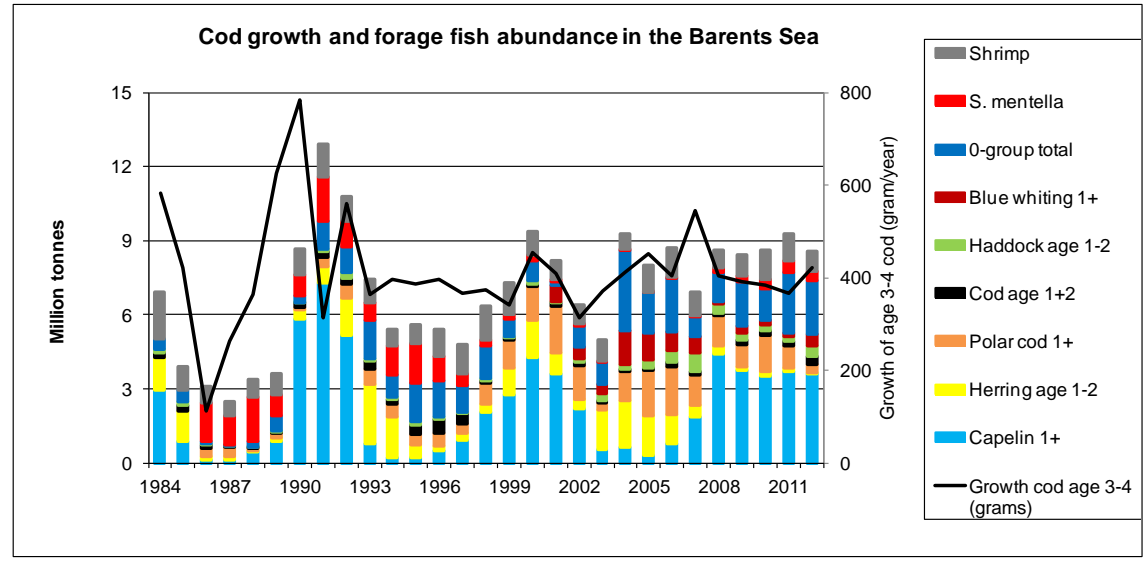

Note: Temporal development in cod individual growth (age 3-4, grams) and prey abundance (million tonnes) for the period 1984-2012 (ICES 2013d).

\section{Advice on the important trade-offs which should be considered in fisheries management}

The Baltic Sea provides a clear example of trade-offs affecting only three species and hence is visually simple to present, so we will examine this area in detail. As seen above, the presence of a large cod stock has effects on both prey stocks and the cod stock itself: the high stock and hence high yield is associated with decreased survival and yield of sprat and herring, and decreased growth of cod. Hence, a relatively large change in $\mathrm{F}$ of cod, though leading to only small changes in yield of cod, may be associated with large changes in yield of the prey species (Figure 4.8).

Solid black lines in figure 4.8 represent the median yield at the given target fishing mortality across all combinations of target $\mathrm{F}$ on other species. Boxes represent the range of yields derived when excluding the bottom $25 \%$ and the top $25 \%$ ranked yields. Whiskers represent the range of yields derived when excluding the bottom $5 \%$ and the top $5 \%$ ranked yields. Stars represent observations outside the range of 2 sd. A wide box and whiskers implies that the yield of that species is heavily influenced by fishing pressure species other than the one depicted on the $\mathrm{x}$-axis. In contrast a narrow range suggests that the yield is relatively insensitive to variations in fishing pressure on species other than that on the $\mathrm{x}$-axis. 
To give an example, figure 4.8 shows that the average yields at a target fishing mortality of 0.5 for cod across all precautionary combinations of target $\mathrm{F}$ for herring and sprat are 77,000 tons of cod, 170,000 tons of herring and 220,000 tons of sprat. The range of yields derived at the bottom $25 \%$ to top $25 \%$ range of yield (the boxes) and selecting a target fishing mortality for cod of 0.5 is 74,000 to 79,000 tons for cod, 160,000 to 185,000 tons for herring and 175,000 to 240,000 tons for sprat. The narrow range of variation for cod under cod fishing pressure (top left, box covers the median $+/-3 \%$ at $\mathrm{F}=0.5$ ) indicates that cod yield is relatively insensitive to fishing pressure on the other species. Conversely the wider variation for herring under changes in herring $\mathrm{F}$ (centre plot, box covers the median $+/-9 \%$ at $\mathrm{F}=0.3$ ) indicates that yield for this species is sensitive to fishing pressure on the other species.

The elements in the diagonal from the top left corner to the bottom right corner are similar to the way yield as a function of $\mathrm{F}$ is represented in single species advice. Hence, they represent the change in yield of the specific species that we can obtain by changing the fishing mortality on that species. Off-diagonal elements represent the effects of species interaction. For example, the change in mean yield of sprat as cod fishing mortality is increased shows the effect of the resulting lower cod stock, which then eats less sprat resulting in higher average yields of sprat.

In addition to the effect that different fishing levels may have on yield, SSB of the three stocks is also affected. To ensure precautionary management, it is important to ensure that each stock has a low probability of falling below the reference points at which recruitment is impaired. These levels are indicated in figure 4.9. It is clear that the cod biomass is on average two to three times greater than the lower limit reference point and hence the proposed $\mathrm{F}$ values would be precautionary. In contrast, high fishing mortalities on sprat or herring are not precautionary when the cod fishing mortality is low, as the combined effect of natural mortality and fishing mortality would then drive the stock below the upper limit reference. Therefore, if cod is fished at an $\mathrm{F}$ of below $\mathrm{F}_{\mathrm{MSY}}$, the $\mathrm{F}_{\mathrm{MSY}}$ and yield of sprat and herring will have to be reduced accordingly. 
Figure 4.8. Graphical representation of yield in a multispecies environment in the Baltic Sea
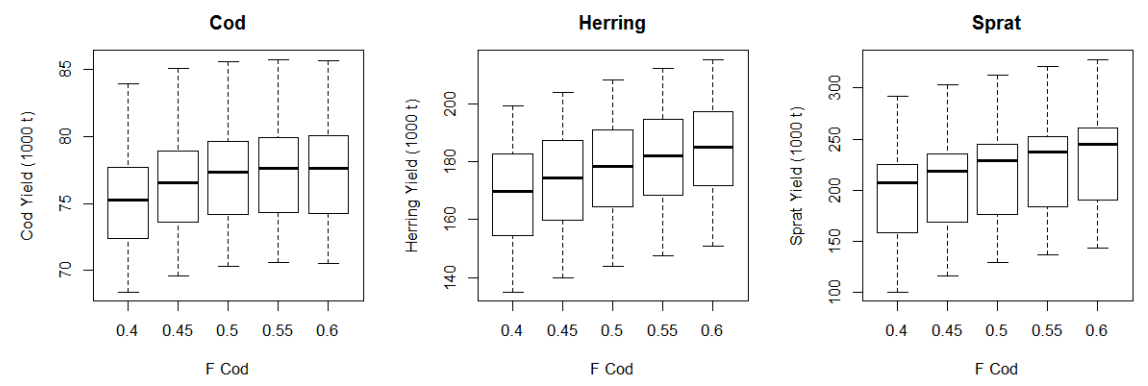

Cod
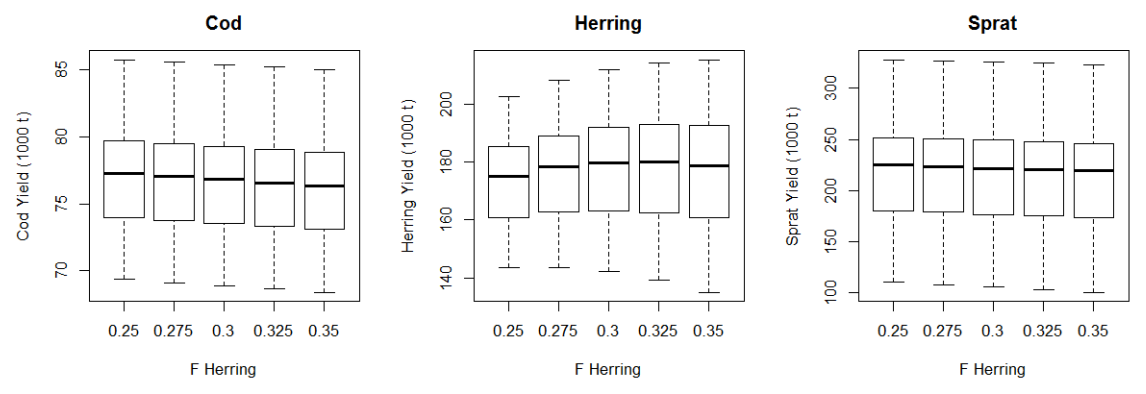

$\begin{array}{lllll}0.25 & 0.275 & 0.3 & 0.325 & 0.35\end{array}$

F Herring

Cod
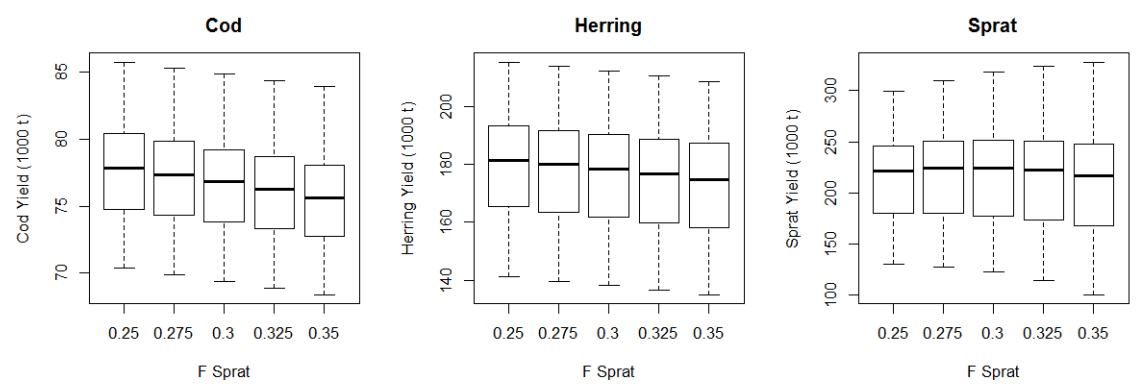

Note: Each column represents the effect of varying target fishing mortality on all species in turn on yields of a specific species. Thus, the right-hand column depicts the yield of sprat on the $y$-axis under different target fishing mortalities on cod (top), herring (middle) and sprat (bottom) on the x-axis.

For ecosystems with a greater number of dominant species, the approach similar to that described above for the Baltic quickly leads to unwieldy figures as the number of important species increases. In these cases, the figures can be screened to identify the importance of different interactions and the results of this screening visualized as shown in table 4.1. In the Baltic Sea, yields of herring and sprat are strongly affected by the target $\mathrm{F}$ on cod and the effect of changes in predation on yield is as large as or larger than the effect of target $F$ on herring. Hence, if cod biomass or distribution show even moderate changes, the $\mathrm{F}_{\mathrm{MSY}}$ 's of herring and sprat should be updated accordingly. Similar plots for the North 
Sea, though more complex, are still useful to derive an overview of which interactions need to be taken into account (table 4.2).

Figure 4.9. SSB at all combinations of fishing mortality on cod, herring and sprat in the Baltic Sea
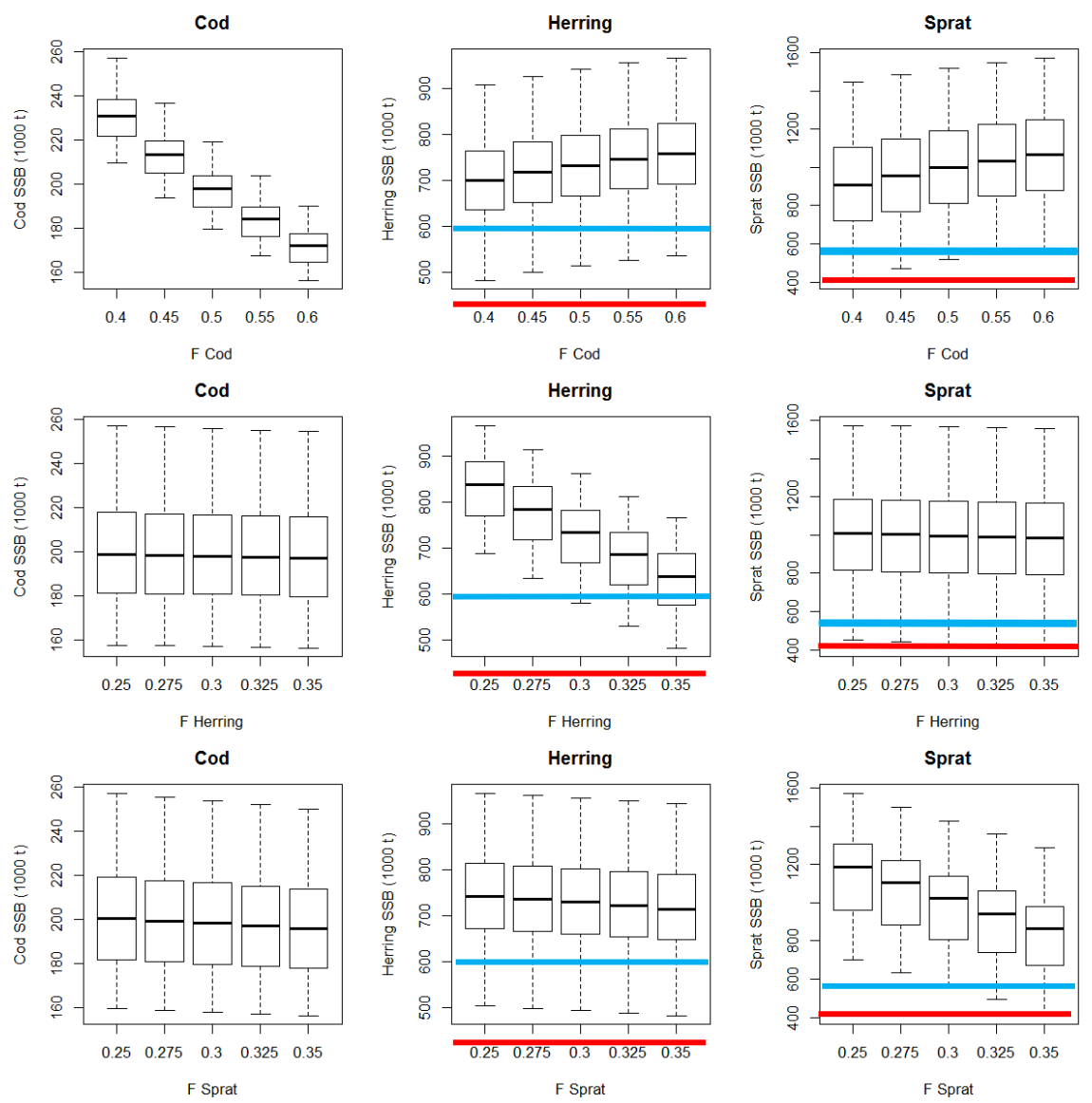

Note: Precautionary reference points (indicating a hard limit, which the stock should always be above and a soft limit, above which the risk of falling below the hard limit is low) for cod are $63,000 \mathrm{t}$ and $88,000 \mathrm{t}$, for herring $430,000 \mathrm{t}$ and $600,000 \mathrm{t}$ and for sprat 410,000 $\mathrm{t}$ and 570,000 t. Hard limits are indicated with red lines, soft limits with blue lines. The lines are not visible on the plots for cod since all values in the plot are above both limits (ICES 2013a). 
Table 4.1. Importance of fishing mortality (rows) on yield (columns)

\begin{tabular}{|l|l|l|l|}
\hline FiYield & Cod & Herring & Sprat \\
\hline Cod & & & \\
\hline Herring & & & \\
\hline Sprat & & & \\
\hline
\end{tabular}

Note: Dark shading indicates high importance, light indicates low importance. Criteria: Dark: Median, upper and lower whiskers change, medium grey: median, upper and lower whiskers change but change is small, white: no noticeable change in median or whiskers. Black line indicates effects of species F on species yield ICES 2013a).

Table 4.2. Importance of fishing mortality (rows) on yield (columns)

\begin{tabular}{|c|c|c|c|c|c|c|c|}
\hline FIYield & Cod & Whiting & Haddock & Herring & Sandeel & N. pout & Sprat \\
\hline \multicolumn{8}{|l|}{ Saithe } \\
\hline \multicolumn{8}{|l|}{ Cod } \\
\hline \multicolumn{8}{|l|}{ Whiting } \\
\hline \multicolumn{8}{|l|}{ Haddock } \\
\hline \multicolumn{8}{|l|}{ Herring } \\
\hline \multicolumn{8}{|l|}{ Sandeel } \\
\hline \multicolumn{8}{|l|}{ N. Pout } \\
\hline Sprat & & & & & & & \\
\hline
\end{tabular}

Note: Dark shading indicates high importance, light indicates low importance. Criteria: Dark: Median, upper and lower whiskers change, medium grey: median, upper and lower whiskers change but change is small, light grey: upper or lower whiskers change, white: not noticeable change in median or whiskers. Black line indicates effects of species F on species yield (ICES 2012a).

Trade-offs will also have economic implications which can be evaluated with appropriate models. Figure 4.10 shows results from one such model for the three major fisheries in the Central Baltic Sea. The model used was the ecological-economic model described in annex 2 , and the results illustrate that distributing the profit for the three fisheries according to the relative stability allows for exploring potential tradeoffs between countries due to the marked differences in quota each country holds for the three species. A rebuilding of the cod stock for example will generally lead to an increase in profit for all countries. However the absolute gain might be very different between countries. In this example, the model does not separate the different métiers (gill nets, trawls, pots etc.), an effect which would also lead to trade-offs between different fleet-sectors within countries. 
Figure 4.10

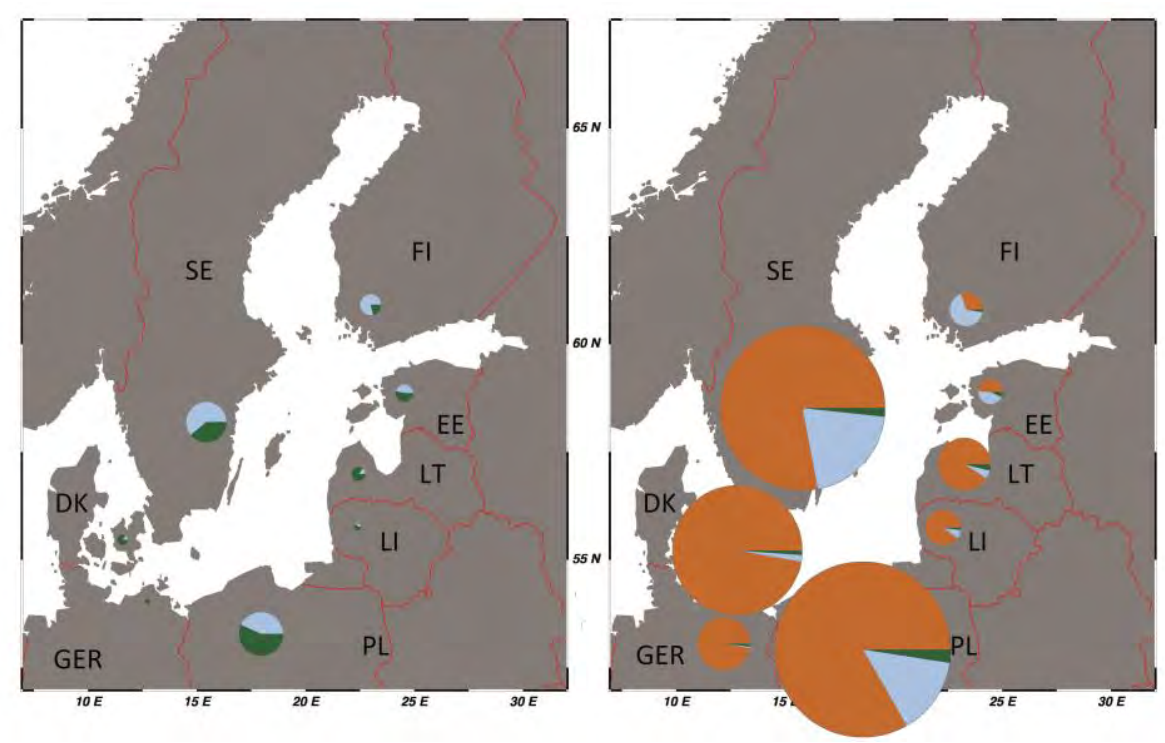

Note: Relative distribution of profits from cod, herring and sprat fisheries in 2006 (left) and simulated with maximum overall profit as objective in the year 2036 (right); largest dot is scaled to 1 and all other scaled accordingly; cod: orange, sprat: green, herring: light blue. (Voss et al. 2013), map produced using Ocean Data View Software (Schlitzer 2013).

\section{Technical guidelines for estimating MSY}

Precautionary fishing mortality targets in a multispecies environment should preferably be defined using stochastic recruitment and a harvest control rule with stepwise adjustment of $\mathrm{F}$ in relation to reference biomasses, rather than deterministic recruitment and a flat $\mathrm{F}_{\mathrm{MSY}}$, unless it can be demonstrated that there is no substantial difference between the results obtained by the two methods. Fishing mortalities, which are unprecautionary at low biomasses resulting from poor recruitment success rather than growth overfishing should also be avoided. Fishing mortalities, which are considered precautionary, differ depending on whether they are derived from deterministic or stochastic simulations, particularly for species with high recruitment variability.

A stepwise harvest control rule should ensure a very low or zero fishing mortality at biomasses below Blim, a gradual increase in fishing mortality between Blim and the upper trigger point (BMSYtrigger) and a constant

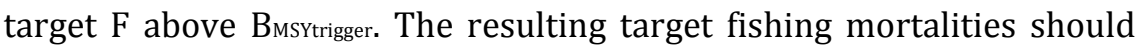
only be considered precautionary when the full harvest control rule is used. Stochastic recruitment should be introduced using a stockrecruitment relationship, which ensures that no recruitment occurs at a biomass of zero and with realistic variation around this relationship. The 
entire time-series should be used when estimating mean weight at age and stock recruitment relationship unless there is indication that parts of the time-series are less reliable or that major, irreversible changes have occurred in the ecosystem.

Even when using a stepwise harvest control rule, some target F combinations can yield predictions whereby a substantial proportion of simulations result in biomasses of at least one species below Blim. These combinations should also be classified as unprecautionary in a multispecies environment. Ideally, numerous stochastic simulations should be performed in order to accurately estimate the probability of falling below Blim for each combination of target fishing mortalities. Combinations for which this probability is greater than the specified risk level should be identified as unprecautionary.

The advice on $\mathrm{F}_{\mathrm{MSY}}$ in a multispecies environment should provide in-

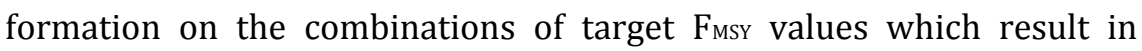
yields above a specified proportion of the maximum sustainable yield of the given species. Maximum sustainable yield of the given species should be derived only from the range of target $\mathrm{F}$ values classified as precautionary. This should be compared to fishing mortalities derived from single species models and differences carefully evaluated.

The advice should indicate in the final output tables which $\mathrm{F}$ target values and stock sizes are inside the historically observed range for each species. Outside this range, yield at a given target $\mathrm{F}$ should considered to have higher uncertainty. This should ensure that it is clear in the advice when values well outside the observed historical range are predicted and hence the confidence in predicted values should be lower and the difference between models is likely to be larger.

\section{Management considerations and trade-offs in mixed-fisheries}

In the current context, the term "multispecies" is used to refer to biological interactions between fish stocks, primarily predator-prey interactions. This helps distinguish biological interactions from the term "technical interactions", which is used to refer to the situation where different species of fish are caught together in the same gear at the same time. For this latter effect, the term "mixed-fisheries" is used. There are similarities between the two effects when it comes to management, but there are important differences too.

One area of similarity between multispecies and mixed-fishery effects is that both approaches take account of multiple fish stocks and recognise that taking management actions for one stock will also have implications 
for the associated stocks. However, the underlying processes, and their susceptibility to management, are quite different. In short, technical interactions arise from human activity, i.e. how, when and where fish are fished. In principle this means that the there is a much closer link between the processes involved and management actions than is the case for the natural processes involved in biological interactions.

In a mixed-fishery, issues arise from difficulties in limiting catches of one species when it is caught together with others. In this situation, where management allows, vessels will continue fishing once their quotas for one or more species are exhausted as they still have fishing opportunities for other stocks caught in the same fishery. This leads to catches exceeding the TAC for some stocks, and to these over-quota catches having to be discarded. As the more restrictive TACs will normally apply to the stocks in the weakest condition, in effect this situation implicitly favours the exploitation of the stronger stocks ahead of the conservation of the weaker stocks. The contrasting approach involves closing all fisheries in the mixed fishery once any of the TACs is exhausted. This approach is known as weak-stock or choke-species management as it gives explicit priority to the weakest stock ahead of the exploitation of the others, and as a result it chokes-off fishing opportunities on the other stocks.

In the context of North Sea demersal fisheries, in recent years cod has been the weakest stock. Reflecting, these two scenarios outlined above have been caricatured as "Sod the cod" vs. "Cod is God" (Gray et al. 2008). The same situation has also acted as the spur for scientific developments to address the management problems associated with mixed fisheries. In particular, Vinther et al. (2004) recognised that the two scenarios represented the extremes of a continuum, and that by making the priorities assigned to each species explicit it would be possible to estimate a set of mixed-fishery TACs. In principle these mixed-fishery TACs would be consistent across the different stocks to remove the problem of one TAC being exhausted before the others. They would also be set to balance the explicit priority given to each stock. In practice, the approach was not adopted and subsequent work on the issue has concentrated on a more flexible approach, which so far has been used to evaluate and advise on the implications of single species TACs given that they will be taken in a mixedfisheries context (Ulrich et al. 2011, ICES 2012d).

At present, most North Sea demersal stocks are subject to multiannual management plans. These are based on single stock advice, which has the side-effect of limiting the possibility of accounting for mixed-fishery effects in TAC-setting. However, the likely implementation 
of a discard ban for EU fisheries will lead to pressure to address the mismatch between catches and fishing opportunities that can occur in mixed-fisheries. In principle, this could be addressed both through managing catches (e.g. through technical measures) and through fishing opportunities (i.e. setting TACs that are more consistent across stocks). In practice however, the implementation of such approaches will require extensive discussion, which will need to involve explicit consideration of the trade-offs between conservation and exploitation. Given the need to achieve long-term management objectives such as MSY, there will also be a need to take a multi-annual approach to management.

A side-effect of addressing technical interactions is that it typically involves explicit accounting for the fishing fleets and the gears in use. This makes transparent the point that the human pressures on fishing stocks arise from the accumulated actions of individual fishing vessels fishing with different gears in different areas. This has implications for the estimation of $\mathrm{F}_{\mathrm{MSY}}$ for a given stock, as although it is largely a biological parameter, reflecting the productivity of the stock, $\mathrm{F}_{\mathrm{MSY}}$ is also based on an assumed exploitation pattern. This reflects the extent to which fish of different age or size classes feature in the catches, and thus results from fishing activity. The exploitation pattern assumed in estimating $\mathrm{F}_{\mathrm{MSY}}$ is typically based on what has recently been observed in the fishery, which gives it some grounding in reality. However, it also follows that it may be possible, in principle, to obtain a higher MSY with a different exploitation pattern, a point which could influence determination of $\mathrm{F}_{\mathrm{MSY}}$ targets. Similarly, it also follows that the exploitation pattern, and thus also the theoretical FMSY, is likely to change with time as vessel activity changes in response to e.g. fishing opportunities and legislative pressures.

\section{Communication and form of advice}

The issue of management advice in a multispecies context can be usefully addressed by using existing single species advice as a starting point. For most European stocks the advice is intended to support TAC management so the management action to be taken will be the setting of an annual TAC. Thus, while the ICES advice is much more comprehensive than just the TAC advice, it is this section which is of most immediate interest to managers. The TAC advice is typically presented in the form of a catch option table which presents possible TACs for the following year along with their basis, and their implications in terms of fishing mortality, SSB at the end of the year etc. Typically, there will also be additional information included 
to assist the choice of options. For instance, options may be presented which are consistent with achieving objectives such as MSY on a defined timescale, or avoiding falling outside of precautionary reference points. Where a multi-annual management plan is in place, the catch option(s) resulting from that will also be indicated.

When the basic principles of the single species catch-option table are extended to a multispecies system the situation gets complex. Even in a relatively simple three-species complex such as the Baltic, when the species are considered together not only does the potential number of catch options increase multiplicatively, but a single catch option would need to include possible TACs for all three stocks and their implications for the other stocks. This volume of information would remove the simplicity that makes the catch-option table a useful approach in the single stock case. This indicates that it may not be desirable to consider the three species together in the advice. Instead, it may be more appropriate to continue to present short term advice in a single-stock format, but to ensure that the multi-species interactions have been considered together with stakeholders at an earlier stage of the process.

Once the complexities of biological interactions in an ecosystem are acknowledged, it becomes apparent that it may not be straightforward to achieve the desired objectives for all exploited species on the same timescale. This dictates a multi-annual approach to long term management where objectives are decided on in advance and then actions are taken over multiple years in order to achieve them. The objectives and the management actions would normally be laid out in a multi-annual management plan. If such an approach were taken, then the multi-species interactions could be explicitly accounted for during the development of the management plan, rather than as part of the annual advice cycle.

Given the trade-offs involved, the development of a multispecies management plan would need to involve a process of discussion and interaction between scientists and other interested parties. This process would involve clear presentation of scientific data and results in order to identify candidate objectives, harvest rules and other components of management. It is at this stage that clear presentation of results, preferably graphically, would be required. The graphs on page $27-30$ provide useful examples of this presentation.

While it is clear that the advice should be based on the best available science, complexity of science does not necessarily imply a need for complex advice. For communication and understanding by stakeholders and the wider public there are advantages to keeping advice as simple as possible. The current single species advice is relatively simple in form 
and there would be advantages of continuity in retaining this form. However, the possibility of keeping this format might depend on the nature of the management plan, and in particular any harvest control rules, that were developed.

It is important to distinguish between multispecies advice and a multispecies harvest control rule. Under a conventional, single-species harvest control rule, the catch of species $A$ to be taken in a given year would be determined only by the state of stock of species $A$ during the preceding year. In contrast, under a multispecies harvest rule, the harvest of species $A$ in a given year might be determined not only by the state of species $A$ in the preceding year and also by the state of species $B$ and $C$. It is quite possible that extensive multi-species analysis could lead to a set of single-species harvest rules for species $A, B$ and $C$ provided that the analysis had shown that these rules would achieve the require objectives when tested against the best understanding of the multispecies interactions between these species. This distinction between multispecies advice and multispecies harvest rules is important for the form of any advice and also for any wider discussion of what is understood by the term multispecies management.

To avoid excessive numbers of options, these should be in accordance with the stated objectives as well as consistent with the precautionary principle.

\section{Applying the framework in other ecosystems}

The framework presented here is generic and should be useful in a wide range of areas. In a data limited situation, the description of the ecosystem should provide at least an indication of where effects of fishing one species on other species (prey or predators) are likely to be important. If knowledge exists on the likely relationships between species, this can be used to tentatively identify the most important interactions and finally, once these are identified, the likely trade-offs can be addressed. The fact that the trade-offs will be estimated in less data demanding ways should not mean that no multispecies advice can be given. Rather, advice should be given on likely effects highlighting the places where more information would be needed to quantify effects. Simply ignoring these predator prey interactions can lead to unprecautionary situations for both predators and prey. It is however difficult to show the usefulness of a generic framework without showing examples, and therefore it is suggested to apply this framework to one or more data poor situations and 
compare the advice stemming from single stock assessments to the resulting multispecies advice.

\section{Acknowledgements}

We wish to thank the Nordic Council of Ministers for financial support and the International Council for the Exploration of the Sea for organisational support. 


\section{References}

Casini M, Cardinale M, Arrhenius F (2004) Feeding preferences of herring (Clupea harengus) and sprat (Sprattus sprattus) in the southern Baltic Sea. ICES Journal of Marine Science, 61:1267-1277.

Casini M, Cardinale M, Hjelm J (2006) Inter-annual variation in herring, Clupea harengus, and sprat, Sprattus sprattus, condition in the central Baltic Sea: what gives the tune? Oikos, 112(3):638-650.

Casini M, Lövgren J, Hjelm J, Cardinale M, Molinero JC, Kornilovs G (2008) Multi-level trophic cascades in a heavily exploited open marine ecosystem. Proceedings of the Royal Society of London, Series B-Biological Sciences, 275:1793-1801.

Casini M, Hjelm J, Molinero J-C, Lövgren J, Cardinale M, Bartolino V, Belgrano A, Kornilovs G (2009) Trophic cascades promote threshold-like shifts in pelagic marine ecosystems. Proceedings of the National Academy of Sciences of the United States of America, 106:97-202.

Eero M, Vinther M., Haslob H, Huwer B, Casini M, Storr-Paulsen M, Köster F (2012) Spatial management of marine resources can enhance the recovery of predators and avoid local depletion of forage fish. Conservation Letters, 5(6):486-492.

FAO (2003) The ecosystem approach to fisheries. FAO Technical Guidelines for Responsible Fisheries. No. 4, Suppl. 2. Rome, FAO. 2003. 112 p.

Gray T, Hatchard J, Daw T, Stead S (2008) New cod war of words: "Cod is God" versus "sod the cod"-Two opposed discourses on the North Sea Cod Recovery Programme. Fisheries Research, 93:1-7.

ICES (2008) Report of the Workshop on Reference Points in the Baltic Sea (WKREFBAS). ICES CM 2008/ACOM:28.

ICES (2011) Report of the Working Group on Multispecies Assessment Methods (WGSAM), 10-14 October 2011, Woods Hole, USA. ICES CM 2011/SSGSUE:10. 229 pp.

ICES (2012a) Report of the Working Group on Multispecies Assessment Methods (WGSAM), 22-26 October 2012, Venice, Italy. ICES CM 2012/SSGSUE:10. 145 pp.

ICES (2012b) Report of the Workshop on North Sea and Baltic Sea Multispecies Trade- offs (WKM-Trade), 9 October 2012, Copenhagen, Denmark. ICES CM 2012/ACOM:71. 15 pp.

ICES (2012c) Report of the Workshop on Integrated/Multispecies Advice for Baltic Fisheries (WKMULTBAL), 6-8 March 2012, Charlottenlund, Denmark. ICES CM 2012/ACOM:43. $112 \mathrm{pp}$.

ICES (2012d) Report of the Working Group on Mixed Fisheries Advice for the North Sea (WGMIXFISH), 21-25 May 2012, ICES Headquarters, Copenhagen. ICES CM 2012/ACOM:22. $94 \mathrm{pp}$.

ICES (2012e) Report of the Working Group on Maritime Systems (WGMARS), 12-14 June 2012, Kiel, Germany. ICES CM 2012/SSGSUE:07. 33 pp.

ICES (2013a) Report of the Benchmark Workshop on Baltic Multispecies Assessments (WKBALT), 04-08 February 2013, ICES Headquarters, Copenhagen. ICES CM 2013/ACOM. 
ICES (2013b) Report of the Baltic Fisheries Assessment Working Group (WGBFAS), 10-17 April 2013, ICES Headquarters, Copenhagen. ICES CM 2013/ACOM.

ICES (2013c) Report of the Working Group on the ICES ACOM/SCICOM Workshop on Ecosystem Overviews (WKECOVER), 7-11 January 2013, ICES Headquarters, Copenhagen. ICES CM 2013/ACOM/SCICOM:01.135 pp.

ICES (2013d) Report of the Arctic Fisheries Working Group (AFWG), 18-24 April 2013, ICES Headquarters, Copenhagen. ICES CM 2013/ACOM.

Möllmann C, Conversi A, Edwards M (2011) Comparative analysis of European wide marine ecosystem shifts: a large-scale approach for developing the basis for ecosystem-based management. Biology Letters, 7:484-486.

Perry AL, Low PJ, Ellis JR, Reynolds JD (2005) Climate change and distribution shifts in marine fishes. Science, 308:1912-1915.

Rudstam LG, Aneer G, Hildén M (1994) Top-down control in the pelagic Baltic ecosystem. Dana, 10:105-129.

Schlitzer, R., Ocean Data View, http://odv.awi.de, 2013.

Ulrich C, Reeves SA, Vermard Y, Holmes SJ, Vanhee W (2011) Reconciling singlespecies TACs in the North Sea demersal fisheries using the Fcube mixed-fisheries advice framework. ICES Journal of Marine Science, 68: 1535-1547.

Vinther M, Reeves SA, Patterson KR (2004) From single-species advice to mixedspecies management: taking the next step. ICES Journal of Marine Science, 61: 1398-1409.

Voss R, Quaas M, Schmidt JO, Hoffmann J (2013) Regional trade-offs from multispecies maximum sustainable yield (MMSY) management options. Marine Ecology Progress Series (submitted). 


\section{Sammenfatning}

Et af de mest grundlæggende forhold i det marine økosystem er interaktionen mellem byttefisk og rovdyr. Gennem denne interaktion påvirker mængden af byttefisk rovfiskens vækst og mængden af rovfisk byttefiskenes dødelighed. Dermed påvirker vores udnyttelse af fisk i toppen af fødekæden det potentielle udbytte af mindre fisk, idet en stor bestand af rovfisk spiser en stor mængde småfisk, der så ikke kan udnyttes kommercielt. Disse effekter introducerer et behov for samfundsmæssige afvejninger omkring. hvordan havets ressourcer bør udnyttes: Det udnyttelsesmønster, der øger bestanden af små fisk såsom sild, er ikke det samme som det, der øger bestanden af store fisk såsom torsk. Denne rapport beskriver en ramme, der kan anvendes til at identificere de væsentligste afvejninger mellem forskellige hensyn i økosystem baseret fiskeriforvaltning. Rammen indeholder en beskrivelse af afgrænsningen mellem forskningens beslutningsarena og den politiske arena, hvordan man opsætter mål for forvaltningen og hvordan man kommunikerer rådgivningen. Konsultationer med interessenter afslørede at flerartsrådgivningen bør være i overenstemmelse med forsigtighedsprincippet, give et fiskeriudbytte tæt ved det maksimale bæredygtie udbytte (MSY), være i overenstemmelse med andre økosystem hensyn og være mulig at formidle til forvaltere og deltagere i det politiske system. Rådgivningen bør indeholde en beskrivelse af økosystemet, en identifikation af de vigtigste interaktioner og rådgivning omkring hvilke afvejninger af forskellige hensyn der er relevante i forvaltningen. Brugen af rammen demonstreres ved eksempler fra tre forskellige økosystemer: Østersøen, Nordsøen og Barentshavet. De tre eksempler er udvalgt, fordi de repræsenterer henholdsvis et økosystem med få dominerende arter, der alle udnyttes kommercielt (Østersøen), et økosystem med mange arter af rovdyr i toppen af fødekæden, hvoraf kun enkelte udnyttes kommercielt (Nordsøen) og et system hvor udnyttelsen af en rovfisk i høj grad påvirkes af fødetilgængelighed (Barentshavet). Et eksempel omkring blandet fiskeri og overvejelser omkring områder med færre data er også inkluderet for at vise at rammen også kan anvendes i disse tilfælde. 



\section{Annex 1 Workshop Summary}

The ICES/NCM workshop on multispecies management took place in Copenhagen at the Carlsberg Academy on 27 February 2013. Aim of the workshop was to present and discuss a broad range of multispecies issues to be included in a guidance document to an audience of scientists, NGOs and managers. Seven presentations were given on:

- Do we need multispecies advice? (Eskild Kirkegaard).

- Setting objectives - a manager's perspective (Stuart Reeves).

- Development of Integrated Assessments in ICES - tactical and strategic connections to multispecies management (Yvonne Walther).

- Trade-offs in multispecies (ecosystem) settings (Jörn Schmidt).

- The possible form of multispecies advice (Anna Rindorf).

- Multispecies management issues in Nordic areas outside the EU (Bjarte Bogstad).

- Experience in Multispecies Fisheries Outside the Northeast Atlantic (Yimin Ye).

The presentations were well received and stimulated a rich discussion about multispecies management. All attendees agreed on the need to take species interactions into account in advice and management. In particular, recent examples like the Eastern Baltic Cod stock show that predator-prey relationships must be considered explicitly. It was also realised that trade-offs are now explicit and the decision space probably larger than assumed in single species advice. Some concerns were raised about the cost that might be related to a system in which more data seems to be needed for assessment and advice. This led to the question on how much data is needed to move from a single species to a multispecies management system. How long will the transition take? Emphasis was also put on the determination of reference points and on the form of the advice. Reference points seem less precautionary in a multispecies assessment then in the single species assessment. This should be clearly described and explained. Communication between science and stakeholders seem even more crucial. How can the even more complex 
information be simplified and integrated into the advice process? Multispecies assessment seems to be more accurate, but at the same time still less precise and more uncertain as single species assessment. How should this be dealt with? It seems to be accepted that there will be no point estimates, although the decision makers would like to have a choice between just a few point estimates. This again calls for a better communication in the whole process.

Overall the discussions favoured multispecies assessment and advice and the major challenge of the process seem to be the communication between science, stakeholders and decision makers and especially the format of the advice given. 


\section{Annex 2 Economic trade-offs}

Multispecies trade-offs for management are already obvious, just taking stock sizes into account. However adding economic considerations might emphasize the need to make explicit management decisions. Here an example from a relatively simple system is given. In the Central Baltic Sea the major commercial species are cod, sprat and herring. The main interaction is the predation of cod on sprat and herring. Thus a larger cod stock might lead to smaller sprat and herring stock and vice verse. There are also some feed back interactions, which possibly strengthen the negative feedback of cod and clupeids, mainly the predation of clupeids on cod eggs. In this example the only interaction taken into account is predation of cod. The economic part in the example consists of costs of fishing and the market price of the species. Herring and sprat are schooling fish and thus the cost of fishing is relatively independent on the stock size. Cod is more dispersed and thus the cost of fishing increases when the stock decreases. The economic parameters for the model were derived from empiric al data, derived from the Annual Economic Report of the Joint Research Centre of the EU (STECF, 2011). For age-specific prices, we use the European reference prices, which are the lowest prices at which imports of cod of specific weight classes, sprat or herring into the European Union are allowed (EC 1999, 2009). The individual models were developed for Central Baltic herring, sprat and Eastern Baltic cod. They are all age-structured (8 age-classes) models to meet the standard assessment models used in ICES. The stock-recruitment function for cod and herring is a basic Ricker equation, whereas for sprat we applied a Beverton/Holt type S/R relationship. The only species interaction included at the moment is the predation of cod on herring and sprat. The equations were derived using output from the SMS model.

The stock-recruitment function as well as the predation estimates are derived using historic data and thus not necessarily capture the observed possible recent change in the Eastern Baltic cod stock. Therefore the results might not reflect quantitatively the short-term development, but show in a qualitative way the long-term development. 
The objective functions maximize the present value of profits for all species combined. We included a weighing factor for the objective functions to be able to scale the importance of one species up or down if wanted. The weighting scheme in the objective function offers the possibility to calculate the actual costs of side conditions (as deviation from maximum profit), e.g. maintaining clupeid stocks above a limit biomass, or of maintaining a certain amount of profit in the single fisheries.

The following graph shows the results of SSB (Figure A1A) and profit (Figure A1B) in the steady state (approximately year 30 of the simulation) for different weighing of cod compared to the clupeids. The line at 1.0 depicts the coupled optimum with equal weight on all species, i.e. the overall optimum. Increasing the weight of cod does not lead to large changes, due to the fact that cod has already a high weight in the model due to its larger market price. Decreasing the weight on cod leads to a strong decrease in optimal cod SSB and therefore profit while concurrently leading to an increase in sprat and herring through a release of predation pressure. The reason for giving more weight to the sprat stock might be to ensure a certain lower biomass of sprat, e.g. for sustaining harbour porpoises or grey seals. The effect on cod biomass, herring biomass and the combined profit is shown in Figure A2. 
Figure A1
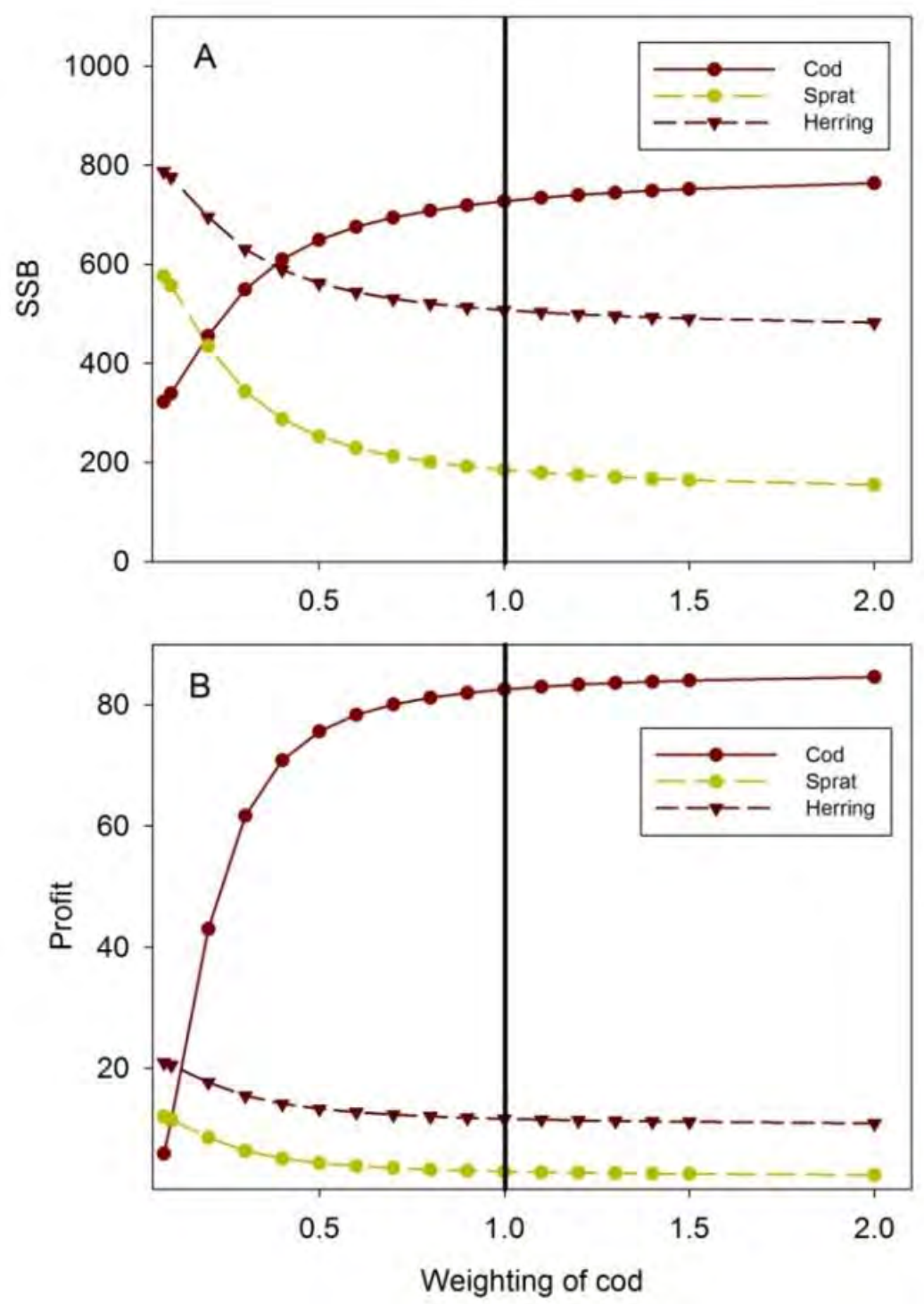

Note: (A) Steady state spawning stock biomass (SSB) and (B) profit for cod, sprat and herring in the Central Baltic Sea. A weighing of 1.0 depicts the scenario with maximum combined profit (modified after Voss et al. 2013). 
Figure A2. Costs of increasing the sprat stock size

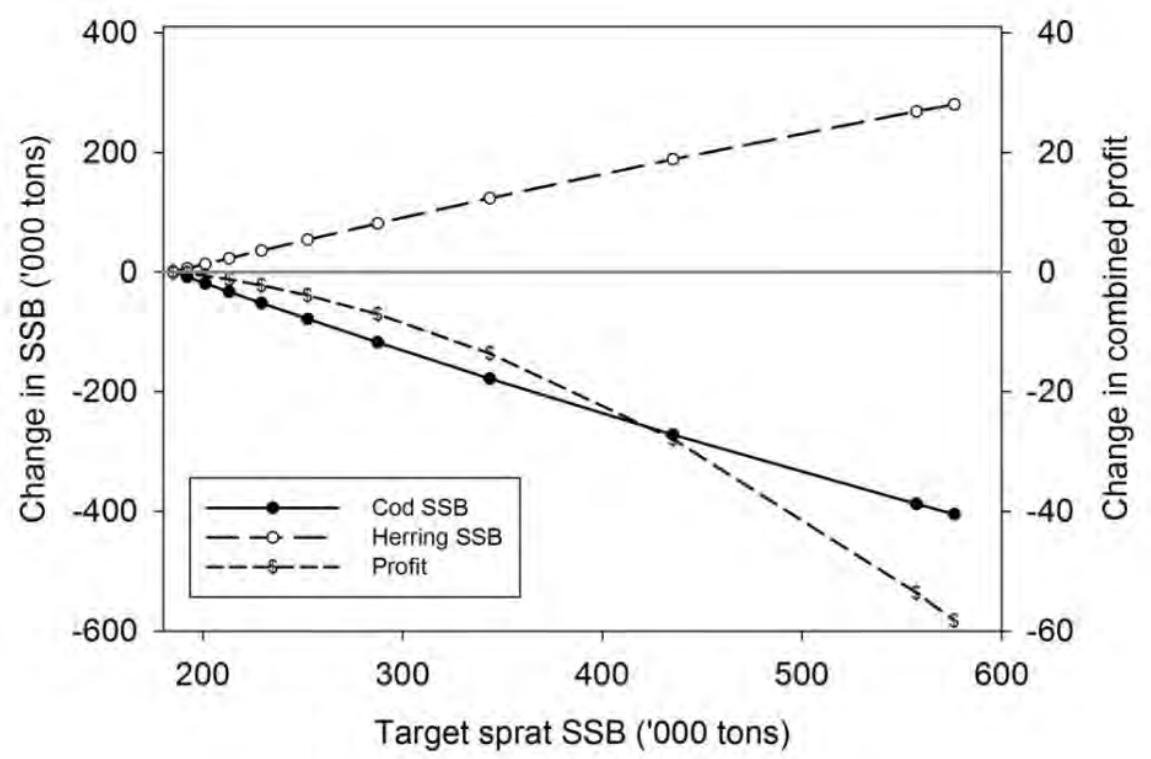

Note: Changes in cod SSB, herring SSB and combined profit if the sprat SSB should be increased (modified after Voss et al. 2013). 
Ved Stranden 18

DK-1061 Copenhagen K

www.norden.org

\section{Framework for Multispecies \\ Assessment and Management}

The report describes a framework that can be used to identify the most important trade-offs in ecosystem based fisheries management. The framework contains a description of how to identify the border between the science and policy domains, how to identify objectives and set goals for management, and how to communicate the management advice. Consultations with stakeholders showed that multi-species management advice needs to be precautionary, provide yields close to MSY, be in accordance with ecosystem constraints and be possible to communicate clearly to managers and policymakers. The use of the framework is demonstrated through examples from three different ecosystems: the Baltic Sea, the North Sea and the Barents Sea. 